\title{
Using Foresight to Shape Future Expectations in Circular Economy SMEs
}

\author{
Anne-Mari Järvenpää, Iivari Kunttu and Mikko Mäntyneva
}

\author{
" The best way to keep something bad from happening is to see it ahead of \\ time ... and you can't see it if you refuse to face the possibility. " \\ William S. Burroughs \\ Author of Naked Lunch
}

\begin{abstract}
Future foresight in business plays a central role in companies' strategic planning, innovation, and product development activities. This is particularly true for firms operating in rapidly changing business environments, in which they may obtain significant competitive advantages by coming up with new innovations and customer solutions. This article studies future foresight mechanisms and practices in innovative SMEs operating in circular economy-related industries. The future demands set by legislation and regulation, consumer buying behaviour, and environmental consciousness, all have a strong impact on an SME's future horizon, in which there may be prosperous business opportunities as well as several challenges. This paper presents a qualitative case study conducted on seven Finnish circular economy-oriented SMEs. The case study reveals that the SMEs in this industrial sector are quite active in foresight activities, and that they have developed a variety of practices for effectively utilizing foresight information in their product development and strategic planning activities.
\end{abstract}

\section{Introduction}

The future of business and industry includes both opportunities and threats. For this reason, industrial actors need to have effective and usable methods and tools to predict possible future changes, both in their own operations and in their business environments (Korreck, 2018). Organizational foresight assumes that even if the future is uncertain, some developments can be foreseen, and thus related options for the business can be considered. This makes it possible to prepare for the future or even to more actively shape it (Cuhls, 2003).

During the last few decades, future foresight in business has become a central part of companies' strategic planning, with clear implications for the development of innovation capabilities (Rohrbeck \& Gemünden, 2011; Uotila et al., 2012). However, as indicated by, for example, Jannek and Burmeister (2007), so far, the empirical research on corporate foresight in Europe has mainly focused on large companies. During the last decade, some further research has been made on foresight in small and medium-sized enterprises (SMEs), but the mainstream is still focused on foresight in larger firms. Consequently, the foresight activities and processes for large firms have been well covered in the related academic literature, whereas foresight at the level of SMEs has received less attention (Stonehouse \& Pemberton, 2002).

Based on existing research, a common denominator is formed between large firms and SMEs when it comes to implementing foresight objectives. Both SMEs and large firms use forecasting to help anticipate future developments, prepare for potential changes in the business environment, and identify relevant risks. Due to the limited resources of SMEs, their planning horizon is typically shorter, and the foresight planning more focused, for example, on short-term research and development $(\mathrm{R} \& \mathrm{D})$ targets, or on specific innovation needs (Jannek \& Burmeister, 2007; Bidaurratzaga \& Dell, 


\section{Using Foresight to Shape Future Expectations in Circular Economy SMEs Anne-Mari Järvenpää, Iivari Kunttu and Mikko Mäntyneva}

2012). In this manner, SMEs often focus their foresight aims in order to support their short-term strategic and operational planning, as well as innovation management (Jannek \& Burmeister, 2007), which often takes place in close interaction with the external environment and stakeholders (Vishnevskiy et al., 2015). Also, strategic foresight can be linked with design-based innovation (Gordon et al., 2019), which involves understanding customers' current and future needs.

The paper focuses on examining the forecasting practices of SMEs operating circular economy businesses. The notion of a "circular economy" is a rather new area of business that has strong development needs involving sustainability, new consumer expectations, and environmental targets. The current rapid changes in business environments and competition, as well as ongoing legislation, cause not only challenges but also new business opportunities for circular economic actors. To prepare for the changes so as to take advantage of them, SMEs operating in this rapidly changing business area need to continuously explore future challenges and opportunities in their business environment. For this reason, developing and utilizing effective foresight practices is essential for circular economy SMEs. Due to their relatively small size, SMEs are often rather streamlined organisations that follow the entrepreneurial intuition of their founders or management, rather than possessing highly sophisticated strategic planning tools and instruments for future foresight (Vishnevskiy et al., 2015). There is therefore an obvious need to investigate and describe the practical approaches that these companies employ in their future foresight activities, both in terms of strategic planning and innovation management.

This paper investigates the future foresight activities of SMEs operating in industries related to the circular economy by seeking answers to the research questions: How do industrial actors and service providers operating in the circular economy foresee future changes in their operational environment? And how do foresight activities affect their business development expectations? The future development of potential market demand may be difficult to evaluate for earlystage industries, which adds risk to the expansion and scaling-up of business operations. To improve understanding of how circular economy-focused SMEs foresee upcoming changes, challenges, and opportunities for their businesses, our study employs the widely applied PESTEL framework that originates from Aguilar's (1967) work, now been tweaked by different perspectives. The detailed questions related to the PESTEL framework deal with political and societal decision-making, economical changes, social issues, technological development, ecological and environmental issues, legislation, and regulatory issues. These are expected to cover the changes, challenges, and opportunities for SMEs operating in circular economyrelated industries. Seeking answers to the research questions in terms of the PESTEL-based framework, this paper contributes empirical research focusing on foresight in SMEs that are operating in relatively earlystage industries related to the circular economy.

\section{Organizational Foresight in Circular Economy- Oriented SMEs}

Organizational foresight activities are used in companies to foresee possible future developments. In this manner, business leaders may consider and prepare for the future in order to act accordingly in a timely manner. As firms gain an understanding of trends, weak signals, and other developments that may impact on their business, they can build preparedness for the future (Korreck, 2018). In this process, the modeling and sensemaking of environmental uncertainty play key roles (Vecchiato, 2015). Moreover, for future-oriented innovative actors, foresight methods may provide a means to actively shape the future, and in this manner, obtain a competitive advantage in the market (Rohrbeck \& Gemünden, 2011; Uotila et al., 2012). Daheim and Uerz (2008) defined organizational foresight as a process related to future intelligence gathering. Rohrbeck (2011) asserted that effective organizational foresight is dependent on organizational capabilities, such as culture and organization (for example, integrating foresight activities within a processes of foresight method sophistication, information usage, people, and networks). However, the literature provides insight into foresight activities conducted in large firms and SMEs, which both seem to have numerous common features. (Bidaurratzaga \& Dell, 2012; Jun et al., 2013).

Stonehouse and Pemberton (2002) argued that not all strategic planning tools and methodologies are suitable for application by SMEs. This is because both the complexity and the time horizons differ between corporate foresight and foresight applied by SMEs. Since SMEs have more limited resources in their activities than larger firms, they are likely to implement foresight case by case. The most important trigger for foresight thinking seems to be when firms are forced to create new products (Jannek \& Burmeister, 2007; Bidaurratzaga 


\section{Using Foresight to Shape Future Expectations in Circular Economy SMEs Anne-Mari Järvenpää, Iivari Kunttu and Mikko Mäntyneva}

\& Dell, 2012). Foresight activities for product and service innovation are then emphasized in the SME context.

Also, the planning horizon of SMEs is relatively short compared to that of large corporations, which can even reach up to 15-20 years (Vishnevskiy et al., 2015). However, SMEs themselves are often quite heterogeneous, since the majority of SMEs operate in conditions that require little foresight implementation (Jun et al., 2013). On the other hand, SMEs operating in areas with rapidly changing business environments or knowledge-intensive innovation networks definitely require sophisticated foresight and visionary capabilities (Uotila et al., 2012). The specific choice for SME foresight implementation should be guided be the objectives of the foresight-related activity, the available resources, and the actual readiness of SMEs to implement such approaches (Vishnevskiy et al., 2015). Thus, the greater willingness an SME has to change itself, the more it is dependent on knowledge that foresight and planning may provide. This can also support the necessary changes and R\&D-related investments.

Another benefit of foresight studies is that they expand the absorptive capacity of SMEs while they interact with the company's environment (Igartua et al., 2010). Vishnevskiy et al. (2015) emphasized that even if some corporate foresight methods have reasonable potential outcomes, they still cannot be applied by SMEs due to the need for allocating significant resources, which usually are not available. The practical relevance for organizational foresight comes from a SME's inability to cope with discontinuous change. Discontinuity within the business environment emphasizes the need to constantly adapt to the environment in order to ensure economic success and long-term survival (Rohrbeck, 2011). When it comes to a firm's ability to foresee longterm future threats and new promising technologies, this is more the objective of long term-oriented corporate foresight.

The concept of a "circular economy" was first used in the literature by Pearce and Turner (1990), who emphasized a circulating flow of value and resources that has restorative effects on the environment. Current academic discussion focuses more on the circular economy as a paradigm notable for its relationship with sustainable development (Prieto-Sandoval et al., 2018). According to Prieto-Sandoval et al. (2018), the circular economy is related to the circulation and recirculation of resources. It derives from a cycle of taking, transforming, using and returning. On the other hand, some firms in circular economy-related industries take resources available from the environment and transform them into products or services. After the transformation, these outcomes can be returned as materials or energy to other value chains ( Park et al., 2010; Ellen MacArthur Foundation, 2013).

The technical or biological conversion of waste into a resource is crucial. After conversion from waste, the resource can be utilized in an industrial process or, alternatively, returned to the biosphere (McDonough \& Braungart, 2010). These two outcomes generate new business opportunities for SMEs. As SMEs operating in circular economy and related industries are in the early stages of industry and product life cycles, their need for foresight practices and their links to strategic planning and business development are essential. Moreover, a rapidly changing operational environment, competition, and regulation can all cause potential future challenges and opportunities that should be handled by means of foresight and planning in these firms.

The actual need for and relevance of foresight are due to a SME's ability to cope with discontinuous change. In an early-stage industrial environment, which is typical of circular economy-related industries, it is probable that there will be both discontinuity and disruption. In some cases, these can be considered threats, but for some adaptive SMEs, these can be characterized as opportunities.

\section{Research Methodology and Data Collection}

This paper is based on qualitative case study research on seven Finnish SMEs operating in the circular economy. These companies provide waste management, recycling services, and make products out of waste materials, as well as designing, building, and operating biogas plants. The data was collected by interviewing company executives, mainly CEOs, in autumn 2019. All the interviews were recorded, transcribed, and then analyzed. The interview questions sought insight on how companies are preparing for changes in their operational environment, and which changes they are expecting.

Table 1 shows an overview of the interviewed companies. The interview questions were constructed by using the PESTEL framework and related to how companies predict future changes, challenges, and opportunities in their operational environment considering the political, economic, social, technological, environmental, and legal aspects. 


\section{Using Foresight to Shape Future Expectations in Circular Economy SMEs Anne-Mari Järvenpää, Iivari Kunttu and Mikko Mäntyneva}

Table 1. Case Descriptions.

\begin{tabular}{|c|c|c|c|c|}
\hline Case & $\begin{array}{c}\text { Interviewed } \\
\text { person }\end{array}$ & $\begin{array}{l}\text { Number of } \\
\text { employees }\end{array}$ & Industry & Core business area \\
\hline $\begin{array}{l}\text { Case } \\
\text { A }\end{array}$ & CEO & 50 & $\begin{array}{l}\text { Combined } \\
\text { facilities support } \\
\text { activities }\end{array}$ & $\begin{array}{l}\text { Waste management, } \\
\text { recycling services and } \\
\text { solutions for households } \\
\text { and companies }\end{array}$ \\
\hline $\begin{array}{l}\text { Case } \\
\text { B }\end{array}$ & CEO & 60 & $\begin{array}{l}\text { The treatment } \\
\text { and disposal of } \\
\text { non-hazardous } \\
\text { waste }\end{array}$ & $\begin{array}{l}\text { Waste management and } \\
\text { recycling services for } \\
\text { households and } \\
\text { companies }\end{array}$ \\
\hline Case C & CEO & 80 & $\begin{array}{l}\text { The treatment } \\
\text { and disposal of } \\
\text { non-hazardous } \\
\text { waste }\end{array}$ & $\begin{array}{l}\text { Waste management and } \\
\text { recycling services for } \\
\text { households and } \\
\text { companies }\end{array}$ \\
\hline $\begin{array}{l}\text { Case } \\
\text { D }\end{array}$ & $\begin{array}{l}\text { Marketing } \\
\text { and sales } \\
\text { coordinator }\end{array}$ & 20 & $\begin{array}{l}\text { Town and city } \\
\text { planning }\end{array}$ & $\begin{array}{l}\text { Environmental } \\
\text { engineering design and } \\
\text { delivering biowaste } \\
\text { treatment solutions. }\end{array}$ \\
\hline Case E & CEO & 40 & $\begin{array}{l}\text { The recovery of } \\
\text { sorted materials }\end{array}$ & $\begin{array}{l}\text { Recovering sorted } \\
\text { materials }\end{array}$ \\
\hline Case F & CEO & 10 & $\begin{array}{l}\text { The dismantling } \\
\text { of wrecks }\end{array}$ & $\begin{array}{l}\text { Recycling services for } \\
\text { wrecks }\end{array}$ \\
\hline $\begin{array}{l}\text { Case } \\
\text { G }\end{array}$ & CEO & 10 & $\begin{array}{l}\text { The } \\
\text { manufacture of } \\
\text { other food } \\
\text { products }\end{array}$ & $\begin{array}{l}\text { Recycling and processing } \\
\text { of oil-based material into } \\
\text { fuel and animal feed }\end{array}$ \\
\hline
\end{tabular}

\section{Results}

The analysis of interview data, as well as secondary data collected from the case companies, revealed several practices for predicting changes in business and operational environments. In this section, we review these practices in PESTEL's six areas, following the interview themes of political, economic, social, technological, ecological, and legal changes in business environments. The obtained results are summarized in Table 2. Following the research questions, the table summarizes both the firms' foresight activities and the interviewed managers' business development expectations in all six areas of PESTEL.

\section{Political aspects}

The interviewed managers agreed that the environmental aspects of their business are nowadays a "hot topic" in public discourse and debate, which also reflects the impact of political decision-making. Recycling and the related themes of the circular economy play a central role in this. For companies operating in the circular economy, predicting future trends in political decision-making is thus essential, and therefore a central part of companies' strategy work:
We actively follow the preparation processes of new legislation because they affect our business a lot. (Case A)

Legislation concerning waste management has been changing recently. Different governments have implemented the norms set by the European Union in different manners, and this has a somewhat varying impact on the local (municipal) level. This all requires us to constantly follow legislation. (Case B)

The interview data clearly shows that the expected changes in the policies regarding environmental issues and waste management are crucial factors for firms Therefore, firms follow relevant policy-making very closely on the management level:

We discuss the expected political changes frequently in our board meetings, and also involve our key stakeholders in this discussion. (Case $\mathrm{C}$ )

The interviewees also emphasized the role of the industrial associations that provide their companies with valuable information on trends involving the 


\section{Using Foresight to Shape Future Expectations in Circular Economy SMEs Anne-Mari Järvenpää, Iivari Kunttu and Mikko Mäntyneva}

climate of political decision-making, which helps them to prepare for future changes, for example, legislation and policies concerning their business. In a similar manner, the industrial associations act as influencers, aiming to promote the industry's viewpoints in political decision-making:

Our inputs regarding the environmental legislation processes are usually collected and transferred through our industrial association. (Case A)

Economic aspects

When asked about the economic factors affecting a firm's current operating environment, most of the interviewed managers mentioned competition in the field of circular economy businesses. This may often lead to price decreases in company products. As this field is increasing due to changes both in terms of consumer trends and environmental policies, new commercial actors are entering the field:

The competitive environment is getting more challenging. The prices of our products have decreased during recent years, mainly because of the increased competition. (Case A)

New actors are coming in on this business, but as initial investments in the production facilities are quite expensive, the newcomers are typically big players who are already operating in some industrial area. (Case C)

However, the circular economy business area is networked in such a way that companies competing with each other also often have areas of collaboration:

The big industrial players in the circular economy sector are our competitors, but still we also collaborate with them in several areas. (Case C)

Social aspects

Our interview data clearly showed that the expectations of the consumers and business-to-business (B2B) customers were dominated by consumer trends. As "green thinking" has become a major feature in almost all areas of consumer markets, products and services are favoured that fulfill high environmental standards. This, in turn, means that circular economy firms operating in both B2B and consumer markets have to understand the importance of consumer expectations regarding issues related to waste management and the use of circular economy products and services:

\begin{abstract}
Face-to-face contacts with our customers are very important. (Case E)
\end{abstract}

Despite the fact that our company is owned by the municipalities of this region, we feel that we have to focus on end users in our services. Serving private consumers is a top priority to us, and we do it in a multichannel manner by using face-to-face contacts, phone, and also increasingly, by digital communication channels such as chat. (Case C)

The interview data also clearly suggested that consumers are increasingly expecting service providers to develop various digital services and online tools to serve their end users: Private consumers expect us to provide them with
digital services. (Case A)

It seems that private consumers favour more and more digital services instead of the traditional communication channels such as phone or email. We have recently launched a chat service and an online store to serve our private customers in certain services. (Case $\mathrm{C}$ )

The interviewed managers also pointed out that both face-to-face customer service and newly established online tools serve for collecting valuable consumer and customer feedback that can be used in further developing a company's services.

\section{Technological aspects}

When discussing the technological challenges facing companies operating in the circular economy, our interviewees emphasized the relatively rapid pace of technological development in the field of material recycling. The companies we spoke with invest a relatively large amount of resources into developing their capabilities and facilities in order to answer to this challenge:

The majority of the waste is nowadays burned. It is an efficient way of processing it, but material recycling is more sustainable. Therefore, all the technological development facilitating material recycling is important for our business. (Case $\mathrm{C}$ )

Our engineering staff is very active in exploring new technological solutions by benchmarking competitors and following the latest developments in our area. (Case D) 


\section{Using Foresight to Shape Future Expectations in Circular Economy SMEs Anne-Mari Järvenpää, Iivari Kunttu and Mikko Mäntyneva}

\section{We participate in development projects in which new technologies are being developed for our business. (Case A)}

Another key technological aspect that arose in the interviews was the strong need to lower carbon emissions in all activities. This puts pressure on to continuously develop methods for logistics and waste collection:

\author{
Logistics and the emissions caused by them will be a \\ big issue in the future. (Case $\mathrm{C}$ )
}

\section{Legal Aspects}

As already discussed at the beginning of this section, legislation has made a remarkable impact on all aspects of circular economy value chains. This means that predicting future changes related to decision-making processes and legislation in this area are increasingly

Table 2. A summary of results obtained from the case interviews.

\begin{tabular}{|c|c|c|}
\hline Political aspects & Economic aspects & Social aspects \\
\hline $\begin{array}{l}\text { Foresight activities: } \\
\text { - Strategic analysis tools, } \\
\text { risk analyses } \\
\text { - Following the media } \\
\text { and information } \\
\text { distributed by the } \\
\text { association } \\
\text { Future expectations: } \\
\text { - Environmental aspects } \\
\text { are a hot topic in } \\
\text { political decision- } \\
\text { making, partly because } \\
\text { the audience pays lot of } \\
\text { attention to } \\
\text { environmental issues; } \\
\text { the circular economy is } \\
\text { one essential part of this } \\
\text { political debate } \\
\text { - The follow-up and } \\
\text { prediction of the } \\
\text { changes in political } \\
\text { decision-making are } \\
\text { included in the } \\
\text { companies' strategy } \\
\text { work } \\
\text { - The role of the } \\
\text { industrial association is } \\
\text { central: the association } \\
\text { transmits political } \\
\text { climate information to } \\
\text { the companies, and tries } \\
\text { to influence on political } \\
\text { decision-making by } \\
\text { viemoting industry } \\
\text { points }\end{array}$ & $\begin{array}{l}\text { Foresight activities: } \\
\text { - Discussions and follow-up } \\
\text { regarding customers and } \\
\text { competitors } \\
\text { - Internal KPIs form a central } \\
\text { tool for predicting the future } \\
\text { Future expectations: } \\
\text { - Competition is increasing all } \\
\text { the time since the number of } \\
\text { service providers is } \\
\text { increasing, leading to a } \\
\text { decrease in prices } \\
\text { - To maintain a position as a } \\
\text { remarkable actor in the } \\
\text { business area requires } \\
\text { investments in production }\end{array}$ & $\begin{array}{l}\text { Foresight activities: } \\
\text { - Customer and consumer } \\
\text { feedback and expectations } \\
\text { are collected through the } \\
\text { customer service function } \\
\text { - Face-to-face contacts } \\
\text { with consumers in } \\
\text { interviews, surveys, and } \\
\text { commercial fairs } \\
\text { - Strong investments in } \\
\text { digital services in } \\
\text { consumer interfaces: } \\
\text { online-tools and chat } \\
\text { services developed to } \\
\text { better serve end users } \\
\text { Future expectations: } \\
\text { - Customer and user } \\
\text { expectations follow } \\
\text { consumption trends } \\
\text { - Consumers are nowadays } \\
\text { aware of environmental } \\
\text { issues, and demand } \\
\text { products and services } \\
\text { meet high environmental } \\
\text { standards } \\
\text { - A key issue is to } \\
\text { understand the behavior } \\
\text { and expectations of single } \\
\text { consumers in their waste } \\
\text { management } \\
\text { - Private consumers in } \\
\text { particular expect digital } \\
\text { services }\end{array}$ \\
\hline
\end{tabular}




\section{Using Foresight to Shape Future Expectations in Circular Economy SMEs Anne-Mari Järvenpää, Iivari Kunttu and Mikko Mäntyneva}

Table 2 (cont'd). A summary of results obtained from the case interviews.

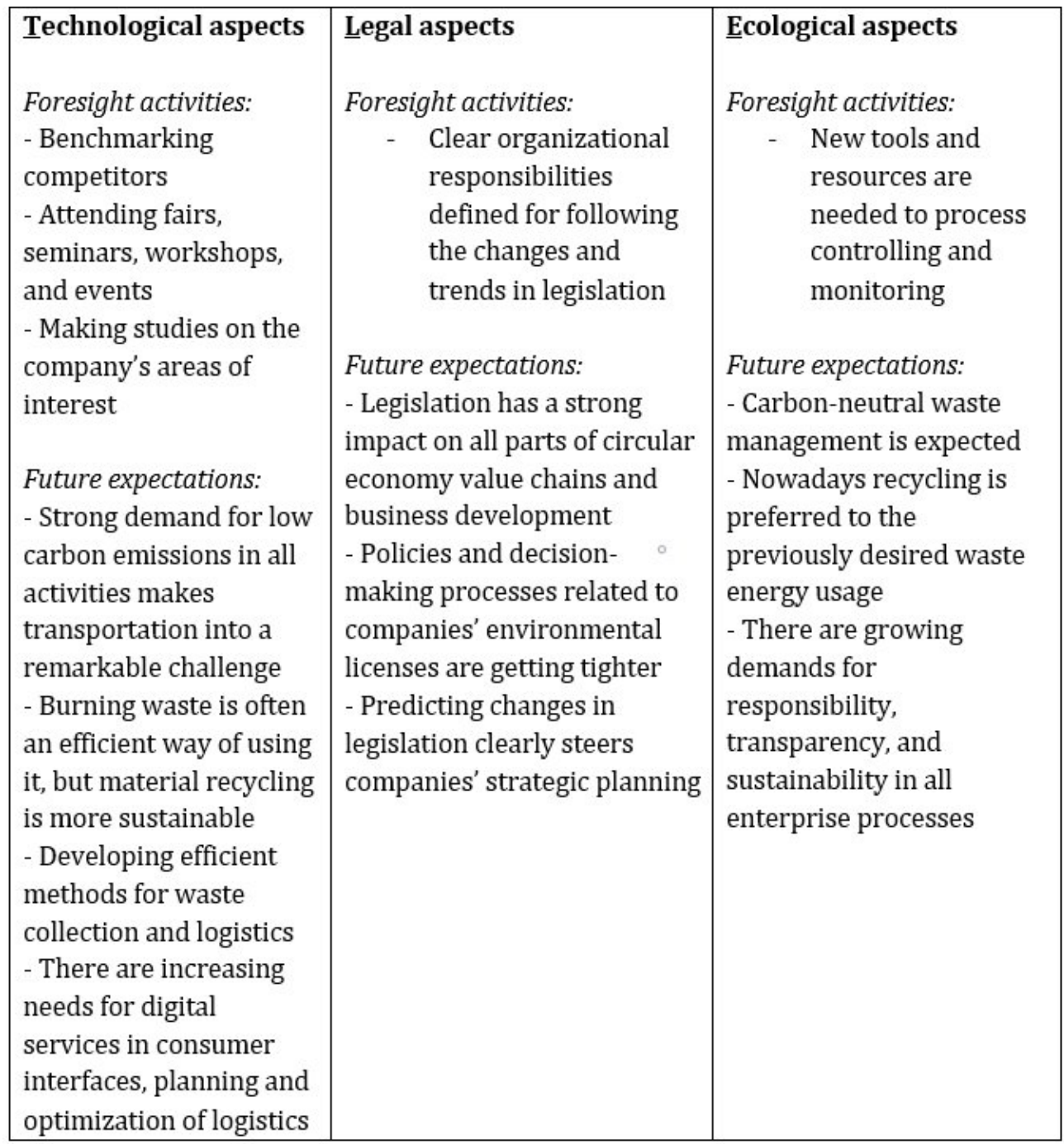

important for business development and strategic planning. The interviewees indicated that the current trend is towards tighter policies and decision-making:

Environmental laws are renewed quite frequently, and they almost always mean new investments for us due to the tighter demands. For this reason, it is very important for us to be able to predict these changes and react to them in advance. (Case C)

\section{Ecological aspects}

As indicated in the previous discussion, the ecological aspects significantly dominate the business environment of the circular economy. The economic aspects in the interview data can be summarized in three main areas. Firstly, nowadays material recycling is preferred to energy usage (waste burning). This is a change compared with previous decades, during which waste was seen as both a good and cost-efficient source for energy production. However, the current target according to government policy to re-use over $50 \%$ of waste material means that energy production based on waste burning should be significantly reduced. Secondly, consumers and societies now expect the minimization of carbon emissions in waste management. This is nevertheless a real test since waste management and recycling are very much dependent on the logistics that cause these emissions. Consequently, one central challenge is to develop solutions for a combination of both logistics and transportation. Finally, companies operating in the circular economy face growing demands in regard to responsibility, 


\section{Using Foresight to Shape Future Expectations in Circular Economy SMEs Anne-Mari Järvenpää, Iivari Kunttu and Mikko Mäntyneva}

transparency, and sustainability in all their processes. These demands are set by consumers and customers, as well as by the government.

\section{Conclusion}

In this paper, we considered the foresight activities of SMEs operating in the circular economy. As indicated in the introduction by Jannek and Burmeister (2007), SMEs typically have narrower capabilities for future forecasting and strategic planning than larger companies. For this reason, foresight activities in SMEs often focus on more practical areas, such as collecting inputs for product development and innovation. Foresight is particularly relevant for SMEs operating in areas with rapidly changing operational environments, customer expectations, or competition (Vecchiato, 2015; Gordon et al., 2019;). In the circular economy sector, all of these areas are experiencing rapid change, which requires firms to undertake continuous foresight and monitoring activities.

In this study, we conducted a comparative case study of seven Finnish circular economy SMEs with a primary goal of understanding how companies foresee the future, and how foresight activities affect their business development. To do this, we employed the well-known PESTEL-analysis tool as a framework. The results of the study, summarized in Table 2, reveal that companies clearly understand the importance of systematic information gathering from their operational environment. As the circular economy is strongly regulated and legislation changes quite frequently, the importance of foreseeing future changes in environmental policies and decision-making was highlighted. Another central area of interest was that our interviewees emphasized the importance of interaction with consumers. As environmental issues, recycling, and resource consumption are all hot topics among consumers, they clearly expect that circular economyoriented firms answer to the growing environmental demands in this area. We found it is also particularly important to be able to serve customers and consumers digitally. For this, there are clear expectations to provide on-line tools for customer interaction.

Based on the results, we conclude that the future demands set by changing legislation and regulation, consumer buying behavior, and environmental consciousness all will have a strong impact on SMEs' future horizons, upon which there may be prosperous business opportunities as well as several challenges.
Among the challenges when an actual window of opportunity for doing profitable business is opening, are the kinds of immaterial rights that are required, when and how to scale-up a firm's capacity, when to expect pay-off for investments, the level of demand and supply, and so on. Future opportunities for business growth include the exploration of new innovative technological solutions, deployment of user innovations, and inputs for new service innovations that can be implemented in digital environments.

As a managerial recommendation, the paper suggests that SMEs operating in circular economy areas should pay attention to future foresight activities. In practice, this would mean gathering systematic information from the operational environment in all relevant areas of PESTEL. To utilize this information in future business development and planning, firms should include the processing and sensemaking of foresight information as one of their key strategic activities. 


\section{Using Foresight to Shape Future Expectations in Circular Economy SMEs Anne-Mari Järvenpää, Iivari Kunttu and Mikko Mäntyneva}

\section{References}

Aguilar, F.J. 1967. Scanning the Business Environment. New York: Macmillan.

Bidaurratzaga, E., \& Dell, M. 2012. Strategic foresight in SMEs: Challenges and solutions- the "future garage process." Proceedings of ISPIM Conferences, (23), 1. Retrieved from:

http://www.sapdesignguild.org/community/book_pe ople/review_design_thinking_d.asp

Cuhls, K. 2003. From forecasting to foresight processes New participative foresight activities in Germany. Journal of Forecasting, 22(2): 93-111. https://doi.org/10.1002/for.848

Daheim, C., \& Uerz, G. 2008. Corporate foresight in Europe: From trend based logics to open foresight. Technology Analysis and Strategic Management, 20(3): 321-336. https://doi.org/10.1080/09537320802000047

Ellen MacArthur Foundation. 2013. Towards the Circular Economy. In Ellen MacArthur Foundation. https://doi.org/10.1162/108819806775545321

Gordon, A., Rohrbeck, R., \& Schwarz, J. 2019. Escaping the 'Faster Horses' Trap: Bridging Strategic Foresight and Design-Based Innovation. Technology Innovation Management Review, 9(8): 30-42.

https://doi.org/10.22215/timreview/1259

Igartua, J.I., Garrigós, J.A., \& Hervas-Oliver, J.L. 2010. How innovation management techniques support an open innovation strategy. Research Technology Management, 53(3): 41-52.

https://doi.org/10.1080/08956308.2010.11657630

Jannek, K., \& Burmeister, K. 2007. Corporate foresight in small and medium-sized enterprises. Corporate Foresight in Small and Medium-Sized Enterprises, Foresight Brief No. 101 Market.

Jun, S.P., Seo, J.H., \& Son, J.K. 2013. A study of the SME technology roadmapping program to strengthen the R\&D planning capability of Korean SMEs. Technological Forecasting and Social Change, 80(5): 1002-1014.

https://doi.org/10.1016/j.techfore.2012.10.022

Korreck, S. 2018. Opening up corporate foresight: What can we learn from open and user innovation? Journal of Innovation Management (JIM), 6(3): 153-177. Retrieved from:

http:/ / hdl.handle.net/10216/116396http:/ / www.open

jim.orghttp://creativecommons.org/licenses/by/3.01

53HANDLE:http://hdl.handle.net/10216/

McDonough, W., \& Braungart, M. 2010. Cradle to Cradle: Remaking the way we make things. North Point Press.

Park, J., Sarkis, J., \& Wu, Z. 2010. Creating integrated business and environmental value within the context of China's circular economy and ecological modernization. Journal of Cleaner Production, 18(15): 1494-1501.

https://doi.org/10.1016/j.jclepro.2010.06.001
Pearce, D.W., \& Turner, R.K. 1990. Economics of natural resources and the environment. JHU Press.

Prieto-Sandoval, V., Jaca, C., \& Ormazabal, M. 2018. Towards a consensus on the circular economy. Journal of Cleaner Production, 179: 605-615. https://doi.org/10.1016/j.jclepro.2017.12.224

Rohrbeck, R. (2011). Corporate foresight: Towards a maturity model for the future orientation of a firm. In Contributions to Management Science, Springer: 203220.

Rohrbeck, R., \& Gemünden, H.G. 2011. Corporate foresight: Its three roles in enhancing the innovation capacity of a firm. Technological Forecasting and Social Change, 78(2): 231-243.

https://doi.org/10.1016/j.techfore.2010.06.019

Stonehouse, G., \& Pemberton, J. 2002. Strategic planning in SMEs - some empirical findings. Management Decision, 40(9): 853-861. https://doi.org/10.1108/00251740210441072

Uotila, T., Mäkimattila, M., Harmaakorpi, V., \& Melkas, H. 2012. Combining foresight and innovation: Developing a conceptual model. In Practice-based innovation: insights, applications and policy implications: 29-47. https://doi.org/10.1007/978-3-642-21723-4_3

Vecchiato, R. 2015. Creating value through foresight: First mover advantages and strategic agility. Technological Forecasting and Social Change, 101: 2536. https://doi.org/10.1016/j.techfore.2014.08.016

Vishnevskiy, K., Karasev, O., \& Meissner, D. 2015. Integrated roadmaps and corporate foresight as tools of innovation management: The case of Russian companies. Technological Forecasting and Social Change, 90(PB): 433-443.

https://doi.org/10.1016/j.techfore.2014.04.011 


\title{
Using Foresight to Shape Future Expectations in Circular Economy SMEs Anne-Mari Järvenpää, Iivari Kunttu and Mikko Mäntyneva
}

\begin{abstract}
About the Authors
Anne-Mari Järvenpää holds a MEng degree in Industrial Service Business (2010) and a BEng degree in Information Technology (2005) from the Häme University of Applied Sciences (HAMK), Finland. Currently, she is studying a $\mathrm{PhD}$ degree in Industrial Management at the University of Vaasa, Finland. Her research topic relates to the circular economy and industrial symbiosis. She is working as a senior lecturer at HAMK on the Degree Programme in Information and Communication Technology, Bioeconomy.

Dr. Iivari Kunttu holds a PhD degree in Information Technology from the Tampere University of Technology (TUT; 2005) and a PhD degree in Economics (management) from the University of Vaasa, Finland (2017). Currently he acts as Principal Research Scientist in HAMK. During 2012-2017 he held an assistant professor position in the Department of Management of the University of Vaasa. He has also held several R\&D manager and $R \& D$ process development specialist positions in the Nokia Corporation and has held project manager positions in TUT. His current research interests include $R \& D$ and innovation management, data analysis, and business development, as well as digital services. His works have been published in such international journals as Pattern Recognition Letters, Machine Vision Applications, Optical Engineering, Journal of Telemedicine and Telecare, Annals of Longterm Care, Technovation, Industry and Innovation, and Technology Innovation Management Review.

Dr. Mikko Mäntyneva holds a PhD degree in Strategic Management from TUT (2004). Currently he is the Principal Research Scientist at HAMK. His research focuses on smart services, innovation management, knowledge management, and customer relationship management. He has authored several scientific articles as well as six books on various management topics.
\end{abstract}

Citation: Järvenpää, A.-M., Kunttu, I., and Mäntyneva, M. 2020. Using

Foresight to Shape Future Expectations in Circular Economy SMEs.

Technology Innovation Management Review, 10(7): 41-50.

http://doi.org/10.22215/timreview/1374 